week's Current Contents has as much historical value as an expired stock option. Where is all this detritus being stored? Well, it's all here in Philadelphia, on disks and backed up on tape. My God, what if a magnetic cloud from Three Mile Island could be devastated. We had better print this stuff in hard covers so it can be buried in a time capsule. And that's what the Contemporary Classics series is all about. Seven volumes, three currently published, of Citation Classics wrapped up in hard covers at about $\$ 40$ per volume.

In his foreword to the first volume on cell biology, Josh Lederberg says that there is " . . much to savour and more to ponder in the menu before us"; a polite way of saying that this is scientific ambergris. You can slice it and look for undigested remains of the scientific diet in the layers, or distil it and hope it will provide a base for some scientific evanescence. James Barrett, editor for these first two volumes, begins the process of stratification by organizing each volume into subtopics and providing some introductory insight into the scientific process under consideration. The reader is then free to browse through the flashbacks by passed over this place? Science history

the authors. Insights laced with reminders from old love letters, rejection notices from funding agencies, projections on the future course of science, snide comments about certain unnamed colleagues, and a few choice words about the editors of Nature (wish I'd thought of that one!).

Many of the authors were clever enough to know that most highly cited papers are methodological or review papers (are you paying attention assistant professors?). Only the minority of us thought that somebody had actually read the conclusions of our classics, and of course we were wrong. Those of you who have not been notified that you have written a Citation Classic take heart, you may have written an Uncited Classic and thus you will not have to return your Nobel prize money.

Is this scientific history? Of course it is, and there's a lot more coming in the next five volumes.

F.J. Bollum is a Professor of Biochemistry at the Uniformed Services University, 4301 Jones Bridge Road, Bethesda, Maryland 20014, USA. The opinions expressed are those of the author and do not reflect the views of the Uniformed Services University or the Department of Defense.

\section{Ray and Raven}

David E. Allen

John Ray: Naturalist. By Charles E. Raven. Cambridge University Press: 1986. Pp.506. Pbk £15, \$24.95.

RAVEN's life of John Ray (1627-1705) must surely be one of the great biographies in the English language, at any rate of a leading scientific figure. Originally published in 1942, at a time of paper rationing and general preoccupation in other directions, it failed to attract the degree of attention it deserved; and though a second edition (in fact scarcely more than a reprint) was brought out in 1950 , that was still well before the major burgeoning of the history of science as an academic discipline. The need for a reissue, preferably in a relatively inexpensive form, has long been glaring and it is difficult to understand why only now one at last has been produced - appropriately, as a volume in the Cambridge Science Classics series.

What makes the book outstanding is the perfect match of author and subject. Raven brought to the task a unique combination of strengths: he had a connoisseur's familiarity with and delight in Latin, the language in which Ray wrote exclusively and with high competence; he had an extensive acquaintance with the British fauna and flora, accumulated through a lifetime's fondness for natural history; he had an intimate knowledge of Cambridge, its surrounding countryside and the workings of its University (as Master of Christ's College he was reputedly the model for Jago in C.P. Snow's novel The Masters); and he was as fully at ease with the seventeenth-century theological background as was only to be expected of a Regius Professor of Divinity.

Yet there is a hint in the book's dedication - "To all who like John Ray have sacrificed security \& careers for conscience' sake" - that the identification went further even than that. As S.M. Walters reminds us in his brief introduction to this reissue, Raven wrote the book at a time when his openly pacifist views, proclaimed with all his customary vigour, had made him a controversial figure, not only within the University but even nationally. Matters never reached the point, as they did with Ray, of his having to sacrifice his University position and even his professional career, but the closeness of the parallels in their lives must have been only too ominously apparent.

Ray had been by no means overlooked, or even under-celebrated, before Raven's study appeared. It was left to Raven, however, to reconstruct in proper detail, with exemplary scholarship, the series of steps by which Ray, almost single-handed, so largely laid the basis of our knowledge of the vascular plants, vertebrates and butterflies of Great Britain (his explorations unfortunately never extended to Ireland) - with some side-forays into its geology and observations on the nature of fossils. Besides exposing many misidentifications made by previous authors and correcting the over-valuation of the contribution made by Ray's young friend, patron and travelling companion, Willughby, Raven went far beyond his predecessors in capturing the adversities, not least the final years of ill health, against which Ray had to struggle and which help to bring him alive as a person.

One particularly noteworthy discovery, the product of a careful winnowing of Ray's plant records one by one, was a putative, overlooked further journey, through the north of England, in 1660. It was evidently this one which initiated the partnership with Willughby, with the historic result of extending Ray's interests to zoology, giving him the means to study plants and animals at first hand over a far wider area than his native East Anglia, and broadening his ambition, and his ultimate achievement, from the compiling of a national Flora to the devising of a pioneer "natural" classificatory system. Never reluctant to venture a judgement or a sharp dissection of the character of one of the many lesser performers on the contemporary scientific scene, Raven set a standard for works of this kind that was immeasurably superior to anything before.

Like most biographers, his admiration for his subject occasionally led him into claiming too much. It is highly questionable, for example, that the development of natural history as a strand in British life "is due to John Ray far more than to any other man". Similarly it is hard to fall in with his conviction that "without Ray's preliminary work there could have been no Linnaeus". Moreover, subsequent research has turned up new information which alters the background colouring in certain significant respects (notably in restoring to prominence the overlooked because unpublished - Joseph Dandridge, described in these pages merely as "famous for his collection of birds' eggs"). But these are very minor defects, certainly not enough to detract from the overal impression of a masterpiece. It is a book which all historians of science should read and which, thankfully, they now no longer have an excuse not to own.

David E. Allen, Lesney Cottage, Middle Road, Winchester, Hampshire SO22 5EJ, UK, is a past President of the Society for the History of Natural History and author of The Naturalist in Britain: A Social History (Allen Lane, 1976).

\section{New in paperback}

- The Ecological Implications of Body Size, by Robert Henry Peters. Publisher is Cambridge University Press, price is $£ 12.50, \$ 16.95$. For review see Nature 308, 474 (1984).

- The Transforming Principle: Discovering that Genes Are Made of DNA, by Maclyn McCarty. Publisher is Norton, price is $\$ 5.95$, $£ 4.95$. For review see Nature 317, 209 (1985). 